\title{
Reconciliation and Peace Opportunity: A Peace Psychology Analysis on Venezuela Crisis
}

\author{
Umar Mubdi \\ International Peace and Conflict Studies Program, Collegium Civitas, Warsaw, Polandia \\ umubdi@gmail.com
}

\begin{abstract}
The Venezuela crisis is an intersection between political turmoil, economic crisis, mismanagement of natural resources, poverty, and health issues. The root causes of the crisis can be examined by using a peace psychology analysis, chiefly the concept of moral disengagement. This perspective is useful for looking at the Venezuelan crisis in a different approach and at the same time, addressing peace efforts. One of the things that need to be pursued by domestic actors and humanitarian intervention is reconciliation. This reconciliation must meet the pre-conditions for the dialogue and peace agenda.
\end{abstract}

Keywords: Venezuela Crisis, Peace Psychology, Moral Disengagement, Reconciliation.

\section{INTRODUCTION}

Political upheaval parallel to the worsening economic conditions in Venezuela has caused a humanitarian crisis in all public sectors. Corruption, inflation, repressive regime measurement, and government social control that restrained civil liberties are contributed in pushing the exodus of Venezuelans into various countries, crossing borders and seeking refuge in tents in Colombia, Mexico, Ecuador, Peru, Brazil, Chile and Argentina (United Nations Higher Commissioner for Refugees (UNHCR), 2019). The domestic crisis in Venezuela has transformed into a humanitarian crisis that requires international intervention. Some international public efforts to restore stability in Venezuela are constrained by the political will of the elite in Caracas who was still trying to regain power.

The Venezuelan crisis indicates that deficits in political and government accountability plus mismanagement of natural resource most likely will direct to widespread crises. The regime arrested a total of 14,986 demonstrators (Organization of American States (OAS), 2019) following inflation, which reached 150,000\% in 2018 (Ellner, 2019). Human rights violations, shortages of livelihood, political strife and corruption, sanitary crises, and international pressure depicted the crisis in Venezuela to the present.

Since the crisis reached its culmination in May 2018, the current situation does not seem to portrait any promise of reconciliation. The "tree trunk" of Venezuela crisis in the form of a presidential crisis is even more acute with the emergence of new contestants in the opposition body at the National Assembly. Parliamentary election which is supposed to be held in 2020 began to be swayed by the one-sided declaration of Luis Parra as the handle of the National Assembly's legislative control (Ellsworth, 2020). In fact, Juan Guaido should be elected the second time this year. Guaido could not join the election at the National Assembly because of Parra blocked. Consequently, 
the new political contestation between Guaido and Parra resulted in violent and conflicts between their supporters.

Political elites are still competing for power while the public is experiencing the severity of the crisis. Nicolas Maduro, as president, currently controls the police, military, and state-run oil companies (Laya, 2020). In the other side, the oppositions encounter conflicts within their parties. The international intervention has also increasingly grown through the claim of legitimacy from Russia and China for Maduro. While the United State, Brazil, and some South American countries support Guaido as legitimate interim president of Venezuela.

The actual conditions of the Venezuela crisis actually require a comprehensive analysis by reviewing the thickened layers of the conflict. For instance, Galtung's triangle of violence identifies the condition with direct, structural and cultural violence. The crisis, alongside with the rise of demonstrations, victims and death tolls, could have been avoided if basic resources are equally distributed among its people and aspirations are heard. The justifications mentioned above are linear with the public responses to demand for rapid long-term changes. In short, the butterfly effect of incompetent government actions generates greater negative impacts. The availability of proportional analysis is beneficial for developing recommendations for the restoration and reconciliation of conflicted agencies. This paper will examine the root causes and effects of the Venezuelan crisis by using a peace psychology approach "moral disengagement" from Bandura (1999).

The Venezuelan conflict has not only inflicted damages to the issues mentioned above, but also affected the psychological state of mind of those impacted. This further includes the behaviors and thoughts related to the act of war and the conscious choice for creating peace. According to Christie, Wagner and Winter (2001) in their book entitled Introduction To Peace Psychology, the working definition of peace psychology, as a bridging point between peace and psychology studies, refers to the set of theories and practices that is developed to prevent and mitigate direct and structural violence. The definition continued that the positive framing of peace psychology promotes the "non-violent" management of conflict and the pursuit of "social justice", commonly referred as peacemaking and peacebuilding (Christie, 2011).

The significance of the use of peace psychology is to fill the gap in explaining the root causes of the Venezuelan crisis. It will address the problem from the sociocognitive aspects of the organism in the form of behavior, thoughts and feelings. Social-cognitive attributes contain the ability to create peace and violence (Deutsch, 1999). Therefore, understanding the behavior of the organisms can't be separated from understanding their personal and social circumstantial. Parallel with that, the study will be valuable to refute the assumption that peace is only an external matter and does not arise from the encouragement of human organisms such as aggressiveness, which leads to conflict and war (Christie et al., 2001).

\section{RESEARCH METHOD}

This research uses a case study method that explicitly addresses Venezuela's presidential crisis in 2019. The use of this method is intended to find out more deeply about the studied object by asking "why" and "how" questions (Yin, 2018). 
The importance of the case study method in analyzing this issue can be seen at several points. First, the 2019 Venezuelan presidential crisis is a relatively actual phenomenon. In reading Gerring (2007), elements of "contemporary set of events" are needed so that the object's analysis still has a historical background but cannot be separated from future analysis projections. The current crisis in Venezuela has roots that go far back since Chavez led several revolutionary policies. That continues to encourage opponents to engage in criticism and deep political divisions. The projection that must be done for this issue is an intervention from external parties to restore national stabilization. The opportunity to relate these aspects makes this case object reliable.

Second, by utilizing the case study method, Venezuela's crisis issue can be analyzed using a cross-case analysis (Gerring, 2007). Consequently, apart from a political perspective, this research's object will also be reviewed from the perspective of peace psychology. The opportunity to use multiple perspectives is what makes this method relevant.

\section{THEORETICAL FRAMEWORK}

\section{SOCIAL-COGNITIVE THEORY}

As above-mentioned in the introduction, social-cognitive theory can be understood as a perspective where an individual tries to control his thoughts and behavior based on the process of self-regulation (Bandura, 1999). Moral agents are then guided by a system of self-regulation to do things according to internal moral standards. This standard will direct moral agents to behave rightly and avoid faulty behavior because individuals use their internal moral standards to anticipate, monitor, and assess their actions (Bandura, 1999). Bandura further asserted that moral standards and self-regulation could be activated and deactivated. When it is not activated, moral disengagement occurs. A moral agent, in moral disengagement, releases himself from self-sanctions and guilt when carrying out an act that violates internal moral standards. Therefore, that notion attach to unethical decision making.

\section{RESULT AND DISCUSSION}

\section{VENEZUELA PRESIDENTIAL CRISIS 2019}

Norden (2010), in Sowing Conflict in Venezuela: Political Violence and Economic Policy, explain that the conflict that has hit Venezuela has actually occurred since the 1980s due to political violence and centralized economic policies. Before that, Venezuela was one of the most stable and democratic countries in the region.

The introduction section shows a single point of political events that have driven the fluctuations in political and economic stability in Venezuela. The political event was the presidential election in 1998. Hugo Chavez, who was previously arrested for initiating military co-optation in 1992, was finally released two years later by President Caldera. With the support of social groups who want to improve the quality of bureaucracy, anti-corruption, and social-political fundamental structures, Chavez has mobilised political agitation called the Fifth Republic Movement (MVR) by proposing a radical approach to anti-neoliberalism (Hybel, 2019). As a result, Chavez won a vote of 56 per cent and became president of Venezuela in 1999. 
At the beginning of his leadership, Chavez made amendments to the constitution together with the National Assembly to construct a firmer democratic regime. Amendment material that most changed the political, economic and social map in Venezuela is the reaffirmation of the state as a central authority to validate the universal principles of social rights and develop programs to fulfil these rights (Bistoletti, 2019). The implication was that the crucial business sector in sustaining the country's economy, such as oil resources, was taken over by the state. The privatisation of oil resource management announced by Caldera must eventually be stopped.

The Chavez government policy model in 2001 focused on welfare redistribution. The model gives privileges to the lower classes of the poor with subsidies and facilities in various lines, while the middle and upper classes lose their capital and social structure. The approach used by Chavez creates a "zero-sum" framework for governing (Leon, 2019). That is what has aroused resistance from various groups, especially the middle and upper classes against the lower classes. Social polarisation and political conflicts that occur have far-reaching consequences for the next decade.

Finally, the global crisis in 2008-2009 dropped oil prices and harmed the Chavez socialist regime, which mobilised national income from the oil sector. A lousy economy with falling oil prices, hyper-inflation, the spread of crime affected the politics, security, and health of the people who were increasingly suffering. His successor, Nicholas Maduro, was elected president in 2013. As international oil prices continued to decline, Maduro's popularity and acceptability declined. In 2015, political tension intensified when the opposition party won the National Assembly election.

It culminates in the Venezuelan presidential crisis in 2019. This crisis has produced a national crisis: an exodus of refugees, increased crime, a health crisis, hunger and inflation. President Maduro, as the incumbent, was declared to win the election in 2018. However, the election results were much debated the legality and legitimacy. The National Assembly, in 2019, at the same time appointed Juan Guaido from the opposition group as interim president to hold a transitional government. Massive demonstrations from Guaido supporters were organized to reject Maduro's presidency. In contrast, the remaining Maduro group mobilized masses to counter the protest.

\section{VIOLENCE AND HUMANITARIAN CRISIS}

Amid political conflict and economic downturn, the condition of society has worsened. To provide a context for the humanitarian crisis that occurred in Venezuela, indicators of the health crisis show a downward trend since the government no longer published the report in 2015 . Independent sources report that the infant mortality rate has increased at least 30 per cent, and the maternal mortality rate has increased by 65 per cent (Organization of American States (OAS), 2019). Patients who experience serious illnesses such as cancer, kidney failure, and diabetes do not receive adequate treatment and medication. Besides, they reported that approximately 5,000 dialysis patients had edited in Venezuela between 2017 and 2019 due to lack of medical supplies (Organization of American States (OAS), 2019).

One of the doctors sent by Cuba to help recover the health of Venezuelans, Yansnier Arias, told that the regime practiced the health services as political means. He 
reported that oxygen cylinders were utilized as political tools where it was not for the medical emergencies of the day, but to be shared when the election (where Nicolás Maduro participated) was closer, as part of a national strategy to force patients to vote for the government (Casey, 2019).

Along with the health crisis, the food crisis and famine experienced by Venezuelans were the worst in history. In the latest 2018 report of Cáritas Venezuela, 65 percent of children from low socio-economic backgrounds served by Caritas Venezuela and aged under five years old have some degree of malnutrition or were at risk of being malnourished (Organization of American States (OAS), 2019). This crisis was dangerous because it will affect the sustainability of Venezuela's future generations. Growth and development of children who were not optimal collectively will cause serious problems. Scarcity of food and basic needs for adults will lead them to severe illnesses so that they were unable to live independently.

The crisis also resulted in the collapse of significant sectors of public services such as water, electricity and gas. Without it all, people will not be able to survive to undergo their activities and meet their basic needs. As a result of the paralysis of public services, schools, hospitals, and public transportation employer went on strike. It also triggered a massive demonstration in March 2019. Of the 6,211 protests registered in the first 90 days of 2019, 1,668 were linked to precariousness in basic services (Organization of American States (OAS), 2019). There are also reports that 1,032 protests are attributable to the decline in electric power services that affect the development of commercial, educational, domestic, cultural and even public health activities.

Prolonged political conflict makes the regime act offensively to the opposition, demonstrations, journalists, and the workers. These actions led to the human rights violation. Systematic execution of several parties was the dominant colour. A nongovernmental organization, Foro Penal, noted that between January 2014 and May 2019 there were 14,986 arbitrary arrests and at least 8,451 people were still subject to precautionary measures in unfair criminal proceedings for political reasons. On May 7, 2019, the Foro Penal announced that the number of political prisoners in Venezuela was 857 , of which 757 were civilians, and 100 were military (Organization of American States (OAS), 2019).

Also, 107 people were arbitrarily arrested throughout the country, and a significant number of people were reported disappeared. Seven people killed have been confirmed. They are all in Bolivar state, and four of them belong to the indigenous Pemon people (Foro Penal, 2019). There are 58 people reported as wounded by bullets: 15 of them were reported in San Antonio del Tachira; 43 in Bolivar state and at least 17 of them belong to the indigenous Pemon people. A significant number of wounded people was also reported.

In addition to the figures mentioned above, the forms of violence and human rights violations committed by the Maduro regime were the incarceration of demonstrators and opposition; significant and widespread attacks on civil society; murders, tortures, rape, and various forms of sexual abuse, and forced disappearance (Bistoletti, 2019). The Maduro government mobilized its military and repressive power to silence the opposition and the civil society that opposed the regime. 
On another aspect, the sharp decline in oil prices in 2014 had a significant impact on the Venezuelan economic crisis. This condition was exacerbated because, in November 2017, the Maduro regime announced that there would be a restructuring of government debt. This condition makes Venezuelan inflation categorized as hyperinflation. The International Monetary Fund (IMF) projects that Venezuelan inflation will reach 13,000 per cent (Serbin, 2014). The cause of this hyperinflation is addressed by the low world oil prices, the decline in oil production, as well as economic processing errors that burden the Venezuelan government.

\section{VIOLENCE TRIANGLE IN VENEZUELA CRISIS}

The previous chapter shows the complexity of violence empirically because all forms of violence occur and experience intersection within each other. Having used the three type of violence form Galtung's triangle (1998), we can elaborate that complexity further. First, direct violence corresponds with behaviours that threaten or eliminate a person's life or ability to meet his basic needs. Examples are murder, maiming, or psychological manipulation. Based on this understanding, the Venezuelan crisis has claimed several lives and injuries as a result of the government's execution and repressive actions. The object was civil society who criticized the authorities and also the opposition that supported Guaido.

Second, structural violence represents a systematic effort where certain groups do not have the opportunity to access servants and basic needs. It could be said that the gravitational point of the Venezuelan presidential crisis is in this type of violence because Maduro took individual political policies to stop the opposition's opportunity to seize his power. Maduro in 2018 called for elections to be held four months earlier than the due date. Some opposition parties are not allowed to compete. When protests escalated, Maduro submitted a proposal to form a constituent assembly that would draft a new constitution to replace the 1999 Venezuelan Constitution made by Chavez. Many people consider Maduro's proposal as his effort to remain in power without limits. Not to mention matters regarding the dismissal of some Venezuelan oil company employees who opposed the nationalization of the company as well as the termination of basic public facilities such as electricity, water and public transportation.

Third, cultural violence can be understood as violence that comes from the confrontation of certain ideologies and social classes in a majority-minority perspective. After the initial economic crisis that struck in 2008, the opposition who were dissatisfied with Chavez socialism put forward the ideas of freedom, democracy, and bureaucratic modernization to reorganize government. The contestation between the two ideologies continues as it did not seem to improve welfare conditions in public. Besides, the regime also acted repressively against Pemon's indigenous society. Minority groups were ultimately marginalized due to the regime's authorization. Even in the year, there have been casualties from the group due to government violence.

The crisis of the Venezuelan presidency received wide attention from the international public. Some peace intervention efforts have been made to restore domestic stability. For example, the International Contact Group consisting of European Union countries and regional partners. The International Contact Group aims to create conditions and provide support for political processes that can lead to the peaceful restoration of democracy, through transparent and transparent presidential 
elections, following the Venezuelan Constitution, and in the shortest possible timeframe (The International Contact Group (ICG), 2019). Also, the European Union and the regional partners provide humanitarian assistance in the form of access to food; medicines and basic services for the most vulnerable; the socio-economic inclusion of migrants in host communities in neighbouring countries; conflict prevention at borders to reduce tensions; civil society; and legal support to Venezuelan migrants (The International Contact Group (ICG), 2019).

In addition to peace intervention, the international response also came from the United States to demand that Maduro step down from the presidency because it was considered illegal and illegal. Meanwhile, Russia, as a Cuban alliance, also intervened in this crisis to keep Maduro in power. In addition to the crisis experienced by Venezuela, the international public imposed individual sanctions on Maduro and those associated with him for his involvement in human rights abuses, corruption, degradation in the rule of law and repression of democracy.

\section{THE ROOT CAUSES BASED ON MORAL DISENGAGEMENT}

The Venezuelan crisis, in some respects, is closely related to the deprivation of internal moral standards from moral agents. Moral agents in this context can be addressed to the main actors of the crisis, namely the state authority represented by Nicholas Maduro or Chavez, opposition groups by Guaido, and international actors. Pivotal moments in this crisis are always influenced by the behavior and social cognitive of the moral agent. Therefore, Bandura provides a clue and explains the eight mechanisms that can be indicators of inactive self-regulation and moral agents have been uprooted from their standards. In this section, three of these mechanisms will be directly linked to the root causes of the Venezuelan crisis.

First, the "moral justifications" that spur the political crisis. Moral justification as the first mechanism of moral disengagement is a process in which individuals commit wrong actions to others, but such actions are as if justified by morals (Bandura, 1999). At this point, the Venezuela political crisis in a field of ethics is polarized into two grounds (Copp, 2006). Each one is cosmopolitanism and communitarianism. Cosmopolitanism puts the centre of attention on individual freedom, egalitarianism, and universal moral values. While communitarianism believes that the value of individual become meaningful when associated with communalism or public identity. It means that the values are not characterized as universal but are the result of the social construction.

Maduro, when committing structural violence by preventing opposition parties from participating in the 2018 general election, was based on his concerns to vulnerable and poor groups (middle and lower classes). He further stated that the conditions occurring in Venezuela were a result of the people's resistance to racism, discrimination, and labor slavery. Therefore, Maduro reshuffled the directors and technicians of the Venezuelan Petro oil company (PSDV), even without proportionate assessment, in the interest of his politics. Maduro is determined to continue to pursue political policies that focus on social development and social protection (Guerin, 2019). Hence, to establish government stability, Maduro often uses repressive measures against anti-regime groups. In this context, the conclusion that can be captured is 
Maduro justifies the repressive-punitive actions and structural violence by using the ethic of "communitarianism".

Meanwhile, the opposition party and its supporters are trying to sabotage Bolivarian Chavez's political agenda by blindsiding Maduro vigorously (Robinson, 2008). In the aftermath of Maduro's victory in the 2013 presidential election, opposition groups have ignited the political crisis by leading demonstrations and even committing violence. In 2014, there was a violent confrontation by opposition groups using rockets, grenades and attempted coups. On another occasion, the demonstrators' opposition also destroyed a hospital which was repressed forcefully by the Maduro. Opposition groups claim that the government's Socialism policy in the form of redistribution and social justice is the cause of the crisis. According to them, it is time for the government to surrender its sovereignty to the people to deal with democratic governance and improve open market systems. The opposition's claim uses clearly moral justification in the form of "cosmopolitanism" ethic.

Based on above-mentioned, the substantive political crisis is the incompleteness of Bolivarian social reform, which has not resulted in a change of the production model that can guarantee mutual prosperity. As a consequence, Venezuela's social transformation to avoid oil dependence can not yet be carried out. At the same time, opposition groups are using the crisis to strengthen their political position. The contestation of two layers of ethics, cosmopolitanism and communitarianism, as moral justification in committing violence by both parties indeed produces deeper root causes. Maintaining life and safety of living together as human beings are the internal moral standards that become deactivate by the regime and opposition groups in this context.

Second, the moral mechanism of disengagement concerning economic mismanagement is "attribution to blame". Attribution to blame can be understood as a process in which a person does a dangerous action to another party as a result of a coercive situation and not his own decision, thus placing the fault of the behavior on others (Bandura, 1999).

This mechanism found its reality in 2014 when large-scale demonstrations took place in Caracas due to public dissatisfaction in the political and economic sector. The frustration also records astonishing facts with a large number of intentional homicides, violent deaths of unknown intent, and police-involved shootings. The strengthening of the intensity of the chaos was precisely responded poorly by the Maduro regime. Maduro tried to suppress and attack the demonstrators by deploying his military forces to guard the city centre. Direct violence that occurred pushed the rate of migration of Venezuelans to neighbouring countries. Until finally, in the act of government prosecution and violence, Maduro declared a state of emergency. For this occurrence, Maduro appointed America as the culprit. Venezuela and its crisis basically are victims of the 'economic war' of the opposition with support from the United States. Attribution to blame is actually practised by Maduro to justify his repressive actions to demonstrators because the state is in an emergency condition due to the actions of other parties.

The economic war mentioned above is a form of economic mismanagement under Maduro's presidency. Some of the policies that led to this tension were: (i) Maduro printed large amounts of money to overcome the budget deficit but instead led 
to hyperinflation; (ii) the government's policy to control prices for staple goods results in the death of private companies; (iii) swollen foreign debt due to "oil-for-loans" deals with Russia and China; and (iv) sanctions from the United States that prohibit Venezuela from accessing US investors and financial markets (Serbin, 2014).

Third, euphemistic labeling is the use of a neutral language with nuances following moral standards to make faulty behavior seem to be not so inadequate (Bandura, 1999). Maduro is focused mainly on criticism both locally and internationally. When Maduro was criticized about the need for international humanitarian aid, he used language that demonstrated "Western" motivation is only to humiliate Venezuela (Bandura, 1999). He further stressed that Venezuela is indeed in trouble but still under the careful control of the government. The problem experienced by Venezuela is similar to other countries in the world, so it does not need external aid.

Maduro's efforts to respond to any criticism by explaining Venezuela's condition is not as severe as reported, and international parties that have disturbed domestic peace and security are part of euphemistic labeling. Maduro did not want to lose his image as a capable president. As a result, he pulled hard on the demonstrators and the opposition in domestic affairs while at the same time he announced Venezuela was under control to the international public.

On this issue, Maduro experienced a deficit of communication skills in international interactions. The lack of communication in explaining intentions between countries causes misunderstandings that prompt vigilance to "triggering one another". The interaction between the Maduro government and international parties was hindered because of Maduro's scepticism to receive any assistance from other countries. On the other hand, the high suspicion regarding the corruption in the Maduro government occurs parallel with the lack of information released by Maduro to the public. Good communication between parties such as Maduro, the opposition, and international parties is the key to revealing the conflictual situation in Venezuela.

\section{EFFECTS OF VIOLENCE ON THE VENEZUELAN CRISIS}

Based on the above-described, the disconnection of moral agent control to its internal standards has resulted in humanitarian crises and increased violence in Venezuela. Violence in all its forms will undoubtedly harm the social conditions. There are at least three notes regarding the effects of violence in the Venezuelan crisis.

First, the frustration-aggressive theory is defined as a disturbance experienced by someone when trying to achieve his goals which automatically generate aggressive energy and drive. The public in Venezuela from the upper-middle and lower-middle classes desire a stable and sustainable condition. However, the political elite indirectly pushed the people of Venezuela to commit violence because of their hubris in allowing people to contribute to the country rightfully. Hence, the people suffer from massive migration out of Venezuela seeking asylum, rising suicide rates, and widespread hunger and poverty. Violence creates a harm situation, but at the same time, the situation triggers violence.

Second, violence against women touched high numbers during the Venezuelan crisis. Around $50 \%$ of Venezuelan women have experienced violence in various forms (Immigration and Refugee Board of Canada (IRB), 2018). Perpetrators include partners, ex-partners, family members, or people who are close to the victim. This 
phenomenon occurs due to (i) conflict situations that trigger public aggressiveness, (ii) lack of education to women resulting in an inability to self-defence (Mazurana, 2001), and (iii) refugee flows that condition women as vulnerable groups.

Third, violence against children has also increased due to widespread violence in Venezuela. The wave of Venezuelan refugees to Colombia include women and children mostly. They suffer from malnutrition, endemic diseases, and no access to education. The data shows that at least six children die every week due to malnutrition and starvation (Save The Children, 2019). In addition to children who become victims and suffer from the conditions created by violence, they also experience a lot of abuse. The effects that the child will undergo include health problems, anxiety, and even potential as future perpetration (Schwebel, 2011).

\section{PEACE OPPORTUNITY}

Political upheaval in Venezuela has sparked controversy in the making of public policy to overcome crises and economic mismanagement. The government tends to be skeptical of the external actor's acceleration in providing humanitarian assistance. Such an attitude is hampering the improvement of conditions in Venezuela. Parallel with that, the divided opposition body, the contestation between military forces and armed civilian groups, as well as the expanse of poverty and refugee flows, signaled an endless crisis.

There are at least three scenarios that can be introduced concerning the dynamics of the Venezuela crisis. First, the Maduro government succeeded in consolidating domestic politics with opposition groups. Actors are willing to compromise their interests for the sake of a consistent economic program. After the security and economic conditions have improved, the actors are committed to implementing improvements in political and governance management (capacity building) by holding democratic elections.

Second, humanitarian intervention from external actors is achieved following Maduro's political openness due to pressure from several parties, including his incapacity to overcome the crisis. If this scenario is successfully realized, several humanitarian assistance can restore the condition of the Venezuelan public that arranged simultaneously with the formulation of a domestic political solution.

Third, Maduro's skepticism about international public attention and the struggle for power at the National Assembly will remain an attribute of the future crisis. The worst possibility is that public distrust, which is getting stronger, will generate public unrest by armed groups. Meanwhile, Venezuelan military forces in the National Guard were unable to stem the coercive wave. The most rational choice to overcome this condition is to use coordinated military interventions between neighboring countries, the United Nations, and other regional entities.

The first scenario tends to be optimistic, but the most difficult to occur. Maduro still retained control of the state-run oil company and military forces, while the opposition experienced instability. The two domestic actors still provide clear boundaries of interests that are not likely to be compromised shortly. The third scenario is the consequence that must be avoided in the Venezuelan crisis. Thus, the second scenario becomes the best choice to accommodate the crisis experienced by the community as well as to de-escalate the crisis in the domestic political sector. 


\section{RECONCILIATION IN THE VENEZUELA CRISIS}

One of the frameworks in peace psychology that can be applied to realize the second scenario is reconciliation. Reconciliation in the Venezuela crisis becomes a necessity, chiefly referring to the five characteristics described by Lederach (1995). Each of these is (i) structural injustices such as poverty or repressive government measures; (ii) identity conflicts between groups; (iii) contain the history of intergenerational conflict; (iv) the conflicting party is in the close area; and (v) physical violence happens.

Reconciliation can be perceived as restoring relations that were broken during the conflict. In reconciliation, conflicts rooted in the past are decomposed into harmony to produce a shared future. According to the negative peace framework of peace psychology, the need for reconciliation is vital to not only focus on the three prereconciliation processes (peacekeeping, peacemaking and peacebuilding), but also restoring the psychological (mental) function of victims affected by the crisis. The use of peace psychology has enable victims to address their mental issues such as grief, stress and anxiety, as well as psychological issues such as family separation, interpersonal and intergroup distrust, and gender-based violence. Addressing these collective traumas and memories, as well as relieving the community from grudges towards opposition groups could accurately disturb the early cycles of violence and prevent future outbreak of conflict (Christie et al., 2008).

In this paper, reconciliation will contain aspects of "reparation" which means improvement of conditions such as before the conflict, and "justice" relating to the restoration of the dignity of victims and the apology of perpetrators (restorative justice). However, reconciliation itself requires conducive conditions for initiating these processes. Some experts claim that the pre-condition for reconciliation is the existence of an agreement (Cheryl, 2007) or the willingness of the parties to rebuild relations by involving multi-level actors (Lederach, 1995). While the usual negotiating process is used to prevent further conflict eruption and guarantee success, Long and Brecke highlighted four successful steps of reconciliation: public truth telling, justice without revenge, redefinition of social identities, and a call for a new relationship. Other types of conflict reconciliation rely on slow but steady processes of change (Christie et al., 2008).

The crisis that occurred in Venezuela resulted in widespread poverty with the fact that nearly $80 \%$ of the population in Bolivar, Lara, and Miranda was unable to meet food needs (HelpAge International, 2019). Besides, repressive and oppressive actions from the government have killed at least 7000 people since 2018 (Hagan, 2019). When drawn from historical roots, this crisis even occurred long before 1998 when Chavez became president. The current crisis in Venezuela is located at the center of power in Caracas. Therefore, the need for reconciliation is inevitable.

One root of the problem that has made the crisis in Venezuela remain to escalate is the lack of good communication and Maduro's political openness to the international public. At the same point, constructive communication between opposition groups and Maduro also did not manage. Thus, the first recommendation related to the pre-conditions of reconciliation in Venezuela is that external actors (third parties) must strive to create a safe space for dialogue. This effort must pay attention to the 
reluctance factor of the conflicting parties, mainly due to the involvement of other actors who are considered only looking for pragmatic advantages. The dynamics of regional politics in South America can be counted as obstacles to a peace agreement or peace dialogue because each country represents support for each conflicted party. The external actor who is most likely to neutralize the situation is the UN under the General Assembly and The Emergency Relief Coordinator.

The external actor can use his influence to establish initial communication with interim president Juan Guaido, Maduro, as well as the National Assembly. The initial communication was aimed at advocating for parties to stop propelling the crisis and focus on the protection of the Venezuelan. The intensification of communication initiated by the external actors will open a momentum where the conflicted parties consider trusting and requiring the external actors to make peace agreements and dialogues.

After the pre-condition element is obtained, reconciliation can be carried out through a dialogue mechanism, and the substance is governed in the product of legislation and policy. There are at least three issues that must be addressed concerning the Venezuela crisis. First, the security sector. That is in the form of an immediate cessation of violence perpetrated by security forces and armed civilian groups. Such cessation should operate hand in hand with efforts to limit political propaganda from the conflicting parties. Besides, humanitarian assistance to victims who are injured, suffering from illness, hunger, and fear must be fulfilled immediately. Therefore, access to humanitarian intervention in Venezuela is crucial for this shortterm and urgent program.

Second, the restoration of political and social structure in Venezuela (capacity building and democratic-based government). These include public involvement and approval in the process of developing the new Venezuelan constitution; equitable distribution of powers and authorities in each branch of power; and holding democratic general elections by supporting transparency and justice. In the social sector, the government and related domestic actors must develop programs that focus on the fulfillment of citizen's rights in the form of freedom of speech, protection from violence, and fulfilling the basic needs of the public in Venezuela.

Third, at the international level, external actors must continue to supervise the reconciliation process in Venezuela and also provide humanitarian assistance for recovering the situation. Political rhetoric from other countries must also side with Venezuelan integration, not the support of legitimacy claims or accusations of responsibility that could reignite conflict.

These three issues are the substance of the reconciliation process in Venezuela. A further variation in this process is the requirement for expression of "apology" and "forgiveness" through reparations and enforcement of justice. Reparation in the Venezuelan case can be prepared in the form of financial compensation from the perpetrator to the victim. On the other hand, the more critical implementation of reparation is to allocate existing capital to establish educational intervention programs, empowering vulnerable groups, and public health facilities. Such a program of reparations can reduce trauma between generations in Venezuela and open up opportunities for the realization of community efficacy in realizing a shared future. 
Besides, law enforcement, based on the principle of restorative justice, is an essential part of expressing apology and forgiveness. This principle requires that the conflicting parties in Venezuela, both perpetrators and victims, reveal the truth even though it is subjective to obtain a convergence point for the establishment of new relations. Victims receive treatment and assistance to restore their condition while the perpetrators can be detained with several forms of punishment. Basically, restorative justice in the Venezuelan case will be useful to lift the dignity and honor of the parties. Thus, the psychological element of "alienation" from the conflicting parties can be overcome and prevented the repetition of violence in the future.

\section{CONCLUSION}

The conflict in Venezuela has layers that can only be decomposed by cooperation between domestic actors and humanitarian intervention. Several root problems in the perspective of moral disengagement, chiefly moral justification, language refinement, and open communication will be even more vigorous if the two sides of the intervention cannot be attempted. Meanwhile, the Venezuela crisis has caused many sufferers, both in terms of toll, material losses, as well as hunger and displacement. Therefore, one of the efforts that can be taken is reconciliation by completing the pre-reconciliation stage. The power of diplomacy, especially in conditions of crisis at a certain time, will reach a "ripe moment" so that the communication tap begins to open. After that, several peace agendas can be arranged by prioritizing commitment to many people who suffer.

\section{REFERENCES}

Bandura, A. (1999). Moral Disengagement In The Perpetration Of Inhumanities. Personality and Social Psychology Review, 3(2). https://doi.org/https://doi.org/10.1207/s15327957pspr0303_3

Bistoletti, E. L. (2019). The Power Struggles over the Post-Neoliberal Social Security System Reforms in Venezuela and Ecuador. Springer.

Casey, N. (2019, March 17). It Is Unspeakable: How Maduro Used Cuban Doctors to Coerce Venezuelan Voters. New York Times. https://www.nytimes.com/2019/03/17/world/americas/venezuela-cubandoctors.html?ref=nyt-es\&mcid=nyt-es\&subid=article

Christie, D. J. (2011, December 15). Peace Psychology: Definitions, Scope, and Impact. Wiley Online Library. https://doi.org/https://doi.org/10.1002/9780470672532.wbepp200

Christie, D. J., Tint, B. S., Wagner, R. V., \& Winter, D. D. (2008). Peace Psychology for a Peaceful World. American Psychologist, 63(2), 540-552. https://doi.org/https://doi.org/10.1037/0003-066X.63.6.540

Christie, D. J., Wagner, R. V., \& Winter, D. D. N. (2001). Peace, Conflict, and Violence: Peace Psychology for the 21st Century. Prentice Hall/Pearson Education.

Copp, D. (2006). The Oxford Handbook of Ethical Theory. Oxford University Press.

Deutsch, M. (1999). Hope with optimism: A commentary on Brewster Smith's article. Peace and Conflict: Journal of Peace Psychology, 5(1), 17-21. https://doi.org/https://doi.org/10.1207/s15327949pac0501_2

Ellner, S. (2019). Explanations for the Current Crisis in Venezuela: A Clash of 
Paradigms and Narratives. Global Labour Journal, 10(2), 159-169. https://doi.org/10.15173/glj.v10i2.3979

Ellsworth, B. (2020, January 7). Little-known Venezuela legislator becomes Maduro's choice for opposition leader. Reuters. https://www.reuters.com/article/usvenezuela-politics-parra-newsmaker/little-known-venezuela-legislator-becomesmaduros-choice-for-opposition-leader-idUSKBN1Z61CU

Foro Penal. (2019). Report on Repression in Venezuela February 2019. https://foropenal.com/wp-content/uploads/2020/02/REPORTE-ANUAL-2019INGLES-1.pdf

Galtung, J. (1998). Peace by Peaceful means. In Peace and Conflict, Development and Civilizafion (pp. 266-268). Sage Publications India Pvt Ltd.

Gerring, J. (2007). Case Study Research: Principles and Practices. Cambridge University Press. http://lpp.uad.ac.id/wp-content/uploads/2013/09/Case-StudyResearch-Principles-Practices.pdf

Guerin, O. (2019, February 12). Venezuela President Nicolás Maduro Interview: Full Transcript. BBC. https://www.bbc.com/news/world-latin-america-47211509

Hagan, A. (2019, July 5). Venezuela death squads have killed 7000 in 18 months - UN. RFI. https://www.rfi.fr/en/americas/20190705-venezuela-death-squads-havekilled-forc-7000-18-months-un

HelpAge International. (2019). Rapid needs assessment of older people Venezuela. https://reliefweb.int/sites/reliefweb.int/files/resources/Rapid needs assessment of older people in Venezuela.pdf

Hybel, A. (2019). The Challenges of Creating Democracies in the Americas. Palgrave Macmillan.

Immigration and Refugee Board of Canada (IRB). (2018). Venezuela: Violence against women. including non-domestic sexual violence. https://www.ecoi.net/de/dokument/1447403.html

Laya, P. (2020, January 14). Who's in Charge in Venezuela and What May Come Next. Bloomberg. $\quad$ https://www.bloomberg.com/news/articles/2020-01-14/who-s-incharge-in-venezuela-and-what-may-come-next-quicktake

Lederach, J. P. (1995). Preparing for Peace Conflict Transformation across Cultures. Syracuse University Press.

Leon, D. S. (2019). Violence in the Barrios of Caracas: Social Capital and the Political Economy of Venezuela. Springer.

Norden, D. L. (2010). Sowing Conflict in Venezuela: Political Violence and Economic Policy. In W. Ascher \& N. Mirovitskaya (Eds.), Economic Development Strategies and the Evolution of Violence in Latin America. Palrave Macmillan. https://doi.org/10.1057/9781137272690_6

Organization of American States (OAS). (2019). OAS Working Group to Address the Regional Crisis Caused by Venezuela's Migrant and Refugee Flows. OAS Publications.

https://www.oas.org/en/media_center/press_release.asp?sCodigo=E-048/19

Robinson, W. I. (2008). Latin America and Global Capitalism. The Johns Hopkins University Press.

Save The Children. (2019). Help Save Children in Venezuela. https://www.savethechildren.org/us/what-we-do/where-we-work/latinamerica/venezuela 
Schwebel, M. (2011). Promoting the culture of peace in children. Peace and Conflict: Journal of Peace Psychology, 7(1), 1-3. https://doi.org/https://doi.org/10.1207/S15327949PAC0701_01

Serbin, A. (2014). Venezuela in Crisis : Economic and Political Conflict Drivers In the Post-Chávez Era. Global Partnership for the Prevention of Armed Conflict.

The International Contact Group (ICG). (2019, September). EU Works For Political Solutions To The Crisis In Venezuela. European External Action Service (EEAS). https://eeas.europa.eu/sites/eeas/files/factsheet_eu_venezuela_09_2019.pdf

United Nations Higher Commissioner for Refugees (UNHCR). (2019). Trends: Forced Displacement in 2018. https://www.unhcr.org/5d08d7ee7.pdf

Yin, R. K. (2018). Case Study Research and Applications Design and Methods (6th ed.). Sage. 